\title{
COMPARATIVE XPS ANALYSES OF PASSIVE LAYERS COMPOSITION FORMED ON DUPLEX 2205 SS AFTER STANDARD AND HIGH-CURRENT-DENSITY ELECTROPOLISHING
}

\author{
Krzysztof Rokosz, Tadeusz, Hryniewicz, Frank Simon, Stawomir Rzadkiewicz
}

Original scientific paper

In the paper, there are described XPS results of passive layers formed on duplex 2205 (EN 1.4462) stainless steel after a standard (EP50) and high-current density electropolishing (EP1000). The electrolyte based on orthophosphoric and sulfuric acids in proportion 1:4 was used. The survey and high resolution spectra of $\mathrm{Cr} 2 \mathrm{p}, \mathrm{Fe} 2 \mathrm{p}, \mathrm{S} 2 \mathrm{p}, \mathrm{P} 2 \mathrm{p}$ are presented in the paper. Based on the survey of XPS spectrum it was possible to find the contamination of outer sublayer consists mainly of nitrogen, sodium, chloride, potassium and partly oxygen and the inner passive sub-layer consists of iron, chromium, nickel, molybdenum, manganese, phosphorus, sulfur, silicon and partly oxygen. The obtained results show that in the passive layers formed on duplex 2205 stainless steel after a standard (EP50) and high-current density electropolishing (EP1000), the following oxides ( $\mathrm{FeO}, \mathrm{Fe}_{2} \mathrm{O}_{3}, \mathrm{Fe}_{3} \mathrm{O}_{4}, \mathrm{Cr}_{2} \mathrm{O}_{3}$ ), hydroxides (FeOOH, $\left.\mathrm{Cr}(\mathrm{OH})_{3}, \mathrm{CrOOH}\right)$ and salts $\left(\mathrm{FeSO}_{4}, \mathrm{Fe}_{2}\left(\mathrm{SO}_{4}\right)_{3}, \mathrm{FePO}_{4}, \mathrm{CrPO}_{4}, \mathrm{Cr}_{2}\left(\mathrm{SO}_{4}\right)_{3}\right)$ were detected. In the paper, besides iron and chromium compounds identification the authors propose two coefficients for passive surface characterization, i.e. chromium-to-iron coefficient $(\mathrm{Cr} / \mathrm{Fe})$ and phosphorus-to-sulfur $(\mathrm{P} / \mathrm{S})$. These two ratios obtained after the standard electropolishing (EP50) of $2205 \mathrm{SS}$ are higher than those obtained after EP1000 treatment.

Keywords: Duplex 2205 SS; electropolishing; XPS Analysis

\section{Usporedne XPS analize sastojaka pasivnih slojeva nastalih na Duplex 2205 SS poslije standardnog elektropoliranja i elektropoliranja strujom velike gustoće}

Izvorni znanstveni članak U radu su opisani XPS rezultati pasivnih slojeva nastalih na duplex 2205 (EN 1.4462) nehrđajućem čeliku nakon standardnog elektropoliranja (EP50) i elektropoliranja strujom velike gustoće (EP1000). Primijenjen je elektrolit na bazi fosforne i sumporne kiseline u omjeru 1:4. U radu se daju analiza spektri visoke rezolucije Cr 2p, Fe 2p, S 2p, P 2p. Na temelju analize XPC spektra bilo je moguće ustanoviti da kontaminaciju vanjskog podsloja tvore uglavnom dušik, natrij, klorid, kalij i djelomično kisik, dok se unutarnji pasivni podsloj sastoji od željeza, kroma, nikla, molibdena, mangana, fosfora, sumpora, silicija i dijelom kisika. Dobiveni rezultati pokazuju da su u pasivnim slojevima nastalim na duplex 2205 nehrđajućem čeliku nakon standardnog (EP50) i elektropoliranja strujom visoke gustoće (EP1000) otkriveni sljedeći oksidi ( $\mathrm{FeO}_{2} \mathrm{Fe}_{2} \mathrm{O}_{3}, \mathrm{Fe}_{3} \mathrm{O}_{4}, \mathrm{Cr}_{2} \mathrm{O}_{3}$ ), hidroksidi $\left(\mathrm{FeOOH}, \mathrm{Cr}(\mathrm{OH})_{3}, \mathrm{CrOOH}\right) \mathrm{i}$ soli $\left(\mathrm{FeSO}_{4}, \mathrm{Fe}_{2}\left(\mathrm{SO}_{4}\right)_{3}, \mathrm{FePO}_{4}, \mathrm{CrPO}_{4}, \mathrm{Cr}_{2}\left(\mathrm{SO}_{4}\right)_{3}\right.$. Uz identifikaciju spojeva željeza i kroma, autori predlažu dva koeficijenta za obilježavanje pasivne površine, t.j. koeficijent odnosa kroma i željeza $(\mathrm{Cr} / \mathrm{Fe})$ te fosfora i sumpora $(\mathrm{P} / \mathrm{S})$. Ta dva omjera dobivena poslije standardnog elektropoliranja (EP50) nehrđajućeg čelika 2205 viša su od onih dobivenih poslije obrade EP1000.

Ključne riječi: Duplex 2205 SS; elektropoliranje; XPS analiza

\section{Introduction}

Duplex 2205 stainless steel represents a steel of good corrosion resistance combined with high strength. It can be used in chemical process, ship, oil, gas, pulp, paper as well as food industries [1]. This type of steel has a higher general corrosion resistance in sulfuric, phosphoric and nitric acids than that in austenitic stainless steels (304, 304L, and 316, 316L). It has a better pitting resistance and crevice corrosion resistance in sea water as well as high stress corrosion resistance. After electrochemical polishing the passive layers, formed on austenitic stainless steels, differ from those grown in air atmosphere [2 $\div 5]$. The differences in chemical composition between the surfaces after standard electropolishing (EP) and magnetoelectropolishing (MEP) were also observed for

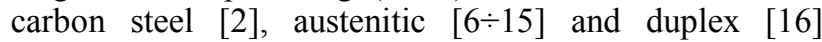
stainless steels.

In this paper, a new electrochemical method, i.e. high-current density electropolishing (EP1000) in a noncommercial electrolyte based on sulfuric and phosphoric acids is presented. The paper is a continuation of the studies performed on AISI 304L stainless steel, presented earlier [17].

\section{Method}

\subsection{Material}

The 2205 duplex stainless steel samples were used for the study, with the material composition presented in Tab.
1. The samples were cut off from a cold-rolled metal sheet of stainless steel. They were prepared in the form of rectangular specimens of dimensions $30 \times 5 \mathrm{~mm}$ cut off the metal sheet $1 \mathrm{~mm}$ thick.

Table 1 Chemical composition of 2205 duplex stainless steel (wt\%) [1]

\begin{tabular}{|c|c|c|c|c|}
\hline \multicolumn{5}{|c|}{ Grade: 2205 UNS No: S32205 } \\
\hline $\mathrm{Cr}$ & $\mathrm{C}$ & $\mathrm{Ni}$ & $\mathrm{Mn}$ & $\mathrm{P}$ \\
\hline $22 \div 23$ & 0,03 & $4,5 \div 6,5$ & 2,00 & 0,030 \\
\hline $\mathrm{Si}$ & $\mathrm{Mo}$ & $\mathrm{N}$ & $\mathrm{S}$ & $\mathrm{Fe}$ \\
\hline 1,00 & $3,0 \div 3,5$ & $0,14 \div 0,20$ & 0,020 & bal. \\
\hline
\end{tabular}

\subsection{Set-up}

The electrochemical polishing operations were performed at the current density of $1000 \pm 10 \mathrm{~A} / \mathrm{dm}^{2}$. The main elements of the high-current density electropolishing (EP1000) set-up were: a processing cell, a DC power supply RNG-3010, the cylindrical electrode (cathode), sample (anode) and connecting wiring. The studies were carried out in the electrolyte of initial temperature of 40 ${ }^{\circ} \mathrm{C}$, with the temperature control of $\pm 5^{\circ} \mathrm{C}$. Generally the final electrolyte temperature was increased up to $55{ }^{\circ} \mathrm{C}$. For the studies, a mixture of sulfuric/orthophosphoric acids electrolyte in the following proportion $\mathrm{H}_{3} \mathrm{PO}_{4}: \mathrm{H}_{2} \mathrm{SO}_{4}=1: 4$ was used. No water was added to this mixture of the concentrated acids. The electrolytic cell made of glass was used, containing up to $500 \mathrm{~cm}^{3}$ of electrolyte solution. Additional set of duplex 2205 steel 
samples treated in the same solution by a standard electropolishing at the current density of $50 \pm 1 \mathrm{~A} / \mathrm{dm}^{2}$ was used as a reference. Those samples were treated in the same solution in temperature of $65 \pm 5^{\circ} \mathrm{C}$. Before the samples were measured they were rinsed with ethanol.

\subsection{Apparatus and procedures}

All XPS studies were carried out by means of an Axis Ultra photoelectron spectrometer (Kratos Analytical, Manchester, UK). The spectrometer was equipped with a monochromatic $\mathrm{Al} \mathrm{K} \alpha(h \cdot v=1486,6 \mathrm{eV}) \mathrm{X}$-ray source of $300 \mathrm{~W}$ at $15 \mathrm{kV}$. The kinetic energy of photoelectrons was determined with a hemispheric analyser set to pass energy of $160 \mathrm{eV}$ for wide-scan spectra and $20 \mathrm{eV}$ for high-resolution spectra. During all measurements, electrostatic charging of the sample was avoided by means of a low-energy electron source working in combination with a magnetic immersion lens. Later, all recorded peaks were shifted by the same value that was necessary to set the $\mathrm{C} 1 \mathrm{~s}$ peak to $285,00 \mathrm{eV}$. For measurements the take-off angle, here defined as angle between the sample surface normal and the electronoptical axis of the spectrometer, was $0^{\circ}$. Hence, the maximum information depth of the XPS method was not more than $10 \mathrm{~nm}$. Quantitative elemental compositions were determined from peak areas using experimentally determined sensitivity factors and the spectrometer transmission function. Shirley background for XPS data analysis was used $[18,19]$. The deconvolution of XPS spectra was done in agreement with the data given in the references $[20,21]$.

\section{XPS survey results analysis}

In Figs. 1 and 2, there are shown XPS survey results of 2205 passive surface layers after standard electropolishing (EP50) and high-current density treatment (EP1000), respectively. In the survey XPS spectra of the passive layer the following elements were detected:

- $\quad$ iron $\left(\mathrm{Fe} 2 \mathrm{p}_{3 / 2}, \mathrm{Fe} 2 \mathrm{p}_{1 / 2}, \mathrm{Fe} 2 \mathrm{~s}, \mathrm{Fe} 3 \mathrm{p}_{3 / 2}, \mathrm{Fe} 3 \mathrm{p}_{1 / 2}, \mathrm{Fe} 3 \mathrm{~s}\right.$, Fe LM1, Fe LM2, Fe LM3),

- chromium (Cr 2s, Cr 2 $p_{3 / 2}, \mathrm{Cr} 2 \mathrm{p}_{1 / 2}, \mathrm{Cr} 3 \mathrm{~s}, \mathrm{Cr} 3 \mathrm{p}_{3 / 2}$, Cr $3 p_{1 / 2}$, Cr LM1, Cr LM2, Cr LM3),

- $\quad$ nickel (Ni 2 $p_{3 / 2}$, Ni $2 p_{1 / 2}$, Ni 2s, Ni 3s, Ni 3p $p_{3 / 2}, \mathrm{Ni}$ $3 p_{1 / 2}$, Ni LM1, Ni LM2, Ni LM3, Ni LM4, Ni LM5),

- molybdenum (Mo 3s, Mo 3p $\mathrm{p}_{3 / 2}$, Mo $3 \mathrm{p}_{1 / 2}$, Mo $3 \mathrm{~d}_{5 / 2}$, Mo $3 \mathrm{~d}_{3 / 2}$, Mo 4s, Mo $4 \mathrm{p}_{3 / 2}$ and Mo 4p $\mathrm{p}_{1 / 2}$ ),

- $\quad$ manganese (Mn 2 $\mathrm{p}_{3 / 2}$, Mn 2 $\mathrm{p}_{1 / 2}$, Mn 2s, Mn 3s, Mn $3 \mathrm{p}_{3 / 2}$, Mn 3 $\mathrm{p}_{1 / 2}$, Mn LM1, Mn LM2, Mn LM3),

- $\quad$ phosphorus (P 2 $\mathrm{p}_{3 / 2}, \mathrm{P} 2 \mathrm{p}_{1 / 2}$ and P $2 \mathrm{~s}$ ),

- $\quad \operatorname{sulfur}\left(\mathrm{S} 2 \mathrm{p}_{3 / 2}, \mathrm{~S} 2 \mathrm{p}_{1 / 2}, \mathrm{~S} 2 \mathrm{~s}\right)$,

- $\quad$ silicon ( $\left.\mathrm{Si} 2 \mathrm{p}_{3 / 2}, \mathrm{Si} 2 \mathrm{p}_{1 / 2}, \mathrm{Si} 2 \mathrm{~s}\right)$,

- $\quad$ oxygen (O 1s, O 2s, O KL1, O KL2, O KL3)

as well as contaminants such as:

- $\quad$ carbon $(\mathrm{C} 1 \mathrm{~s})$,

- $\quad$ nitrogen (N 1s),

- $\quad \operatorname{sodium}(\mathrm{Na} 1 \mathrm{~s}, \mathrm{Na} \mathrm{KL} 1)$,

- chlorine $\left(\mathrm{Cl} 2 \mathrm{p}_{3 / 2}, \mathrm{Cl} 2 \mathrm{p}_{1 / 2}, \mathrm{Cl} 2 \mathrm{~s}\right)$,
- $\quad \operatorname{potassium}\left(\mathrm{K} 2 \mathrm{p}_{3 / 2}, \mathrm{~K} 2 \mathrm{p}_{1 / 2}, \mathrm{~K} 2 \mathrm{~s}, \mathrm{~K} 3 \mathrm{p}_{3 / 2}, \mathrm{~K} 3 \mathrm{p}_{1 / 2}, \mathrm{~K}\right.$ $3 \mathrm{~s})$,

- $\quad$ calcium $\left(\mathrm{Ca} 2 \mathrm{p}_{3 / 2}, \mathrm{Ca} 2 \mathrm{p}_{1 / 2}, \mathrm{Ca} 2 \mathrm{~s}, \mathrm{Ca} 3 \mathrm{p}_{3 / 2}, \mathrm{Ca} 3 \mathrm{p}_{1 / 2}\right.$, Ca 3s).

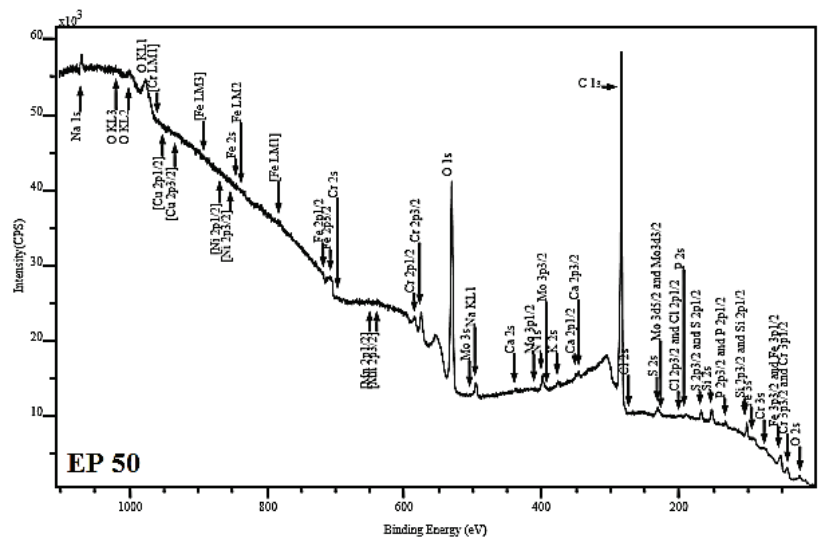

Figure 1XPS survey results of passive surface layer of 2205 duplex stainless steel after standard electropolishing (EP50) within the binding energy of $0-1100 \mathrm{eV}$

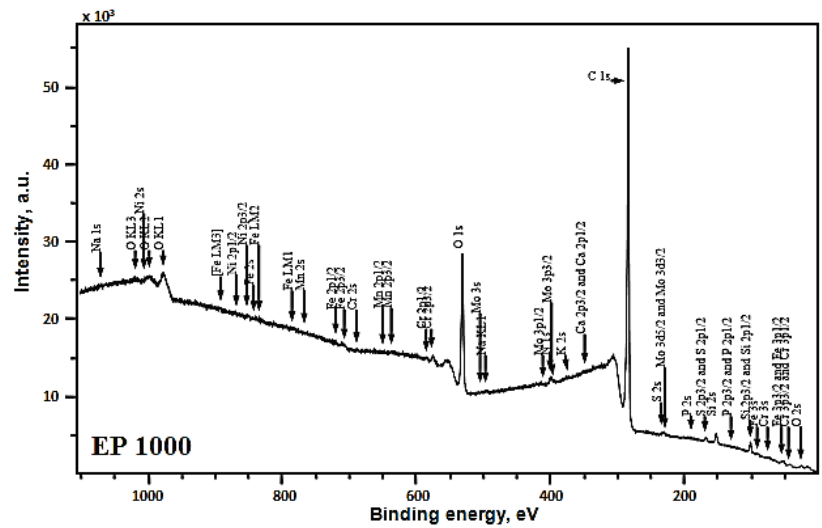

Figure 2 XPS survey results of passive surface layer of 2205 duplex stainless steel after high current density electropolishing (EP1000) within the binding energy of $0 \div 1100 \mathrm{eV}$

\section{High-resolution XPS results analysis \\ 4.1 Iron (Fe 2p) and chromium ( $\mathrm{Cr} 2 \mathrm{p}$ ) high-resolution spectra}

In Fig. 3, the deconvolution of Fe $2 p$ spectra of passive layers formed on 2205 after standard (EP50) and high-current density electropolishing (EP1000) is shown. The difference of the binding energy values between $\mathrm{Fe}$ $2 \mathrm{p}_{3 / 2}$ and $\mathrm{Fe} 2 \mathrm{p}_{1 / 2}$ is in the range from 13,1 to $13,6 \mathrm{eV}$. The $\mathrm{Fe} 2 \mathrm{p}_{3 / 2}$ spectra were deconvoluted into the three component peaks. In some cases it was useful to introduce a further peak, which summarized the high-spin states of iron. Component peaks appearing at binding energies in the range from $706,5 \mathrm{eV}$ to $707 \mathrm{eV}$ showed metallic iron $\left(\mathrm{Fe}^{0}\right)$. Component peaks at binding energy in range from 708,2 to $710,9 \mathrm{eV}$ could be interpreted as the mixed oxide $\underline{\mathrm{Fe}}_{3} \mathrm{O}_{4}$ and the oxides $\underline{\mathrm{FeO}}$ and $\underline{\mathrm{Fe}}_{2} \mathrm{O}_{3}$. Component peaks at binding energies $711,5 \mathrm{eV}, 712,1 \mathrm{eV}, 713,3 \mathrm{eV}, 714,65$ $\mathrm{eV}$ correspond to $\underline{\mathrm{FeOOH}}, \underline{\mathrm{FeSO}}{ }_{4}, \underline{\mathrm{Fe}}_{2}\left(\mathrm{SO}_{4}\right)_{3}, \underline{\mathrm{Fe}} \mathrm{PO}_{4}$ respectively.

In Fig. 4, the deconvolution of $\mathrm{Cr} 2 \mathrm{p}$ spectra of passive layers formed on 2205 after standard (EP50) and high-current density electropolishing (EP1000) is presented. The differences of the binding energy values of 
the two peaks $\mathrm{Cr} 2 \mathrm{p}_{3 / 2}$ and $\mathrm{Cr} 2 \mathrm{p}_{1 / 2}$ are in the range from 9,2 to $9,8 \mathrm{eV}$. The $\mathrm{Cr} 2 \mathrm{p}$ spectra recorded show differences of binding energy equal to about $9,4 \mathrm{eV}$ for the metallic chromium $\left(\underline{\mathrm{Cr}}^{0}\right)$, and $9,8 \mathrm{eV}$ for chromium compounds.

All $\mathrm{Cr} 2 \mathrm{p}$ spectra were deconvoluted into four component peaks assigned. According to the binding energy values found, component peaks at binding energy equal to about $574 \mathrm{eV}$ represent metallic chromium $\left(\underline{\mathrm{Cr}}{ }^{0}\right)$. The other component peaks have binding energy values typical for chromium oxides, hydroxides and salts. Component peaks at binding energies 576,9 eV, $577 \mathrm{eV}$, $577,3 \mathrm{eV}, 578,1 \mathrm{eV}, 578,6 \mathrm{eV}$, correspond to $\mathrm{Cr}_{2} \mathrm{O}_{3}$, $\underline{\mathrm{CrOOH}}, \quad \mathrm{Cr}(\mathrm{OH})_{3}, \quad \underline{\mathrm{CrPO}_{4}}, \quad \underline{\mathrm{Cr}}_{2}\left(\mathrm{SO}_{4}\right)_{3}, \quad$ respectively. Chromium in the oxidation state $\mathrm{Cr}^{6+}$, such as $\mathrm{CrO}_{3}$ and chromates $\left(\underline{\mathrm{CrO}}_{4}{ }^{2-}\right)$ /dichromates $\left(\underline{\mathrm{Cr}}_{2} \mathrm{O}_{7}{ }^{2-}\right)$, is presented as a component peak, with the binding energy $(B E)$ ranging $578,7 \div 579,1 \mathrm{eV}$.

The amount of chromium in the passive layer after standard electropolishing EP50 was about twice higher than iron amount. Chromium-to-iron coefficient $(\mathrm{Cr} / \mathrm{Fe})$ after that electrochemical treatment equals 1,9 (atomic concentration). After high-current electropolishing EP1000, the chromium-to-iron coefficient $(\mathrm{Cr} / \mathrm{Fe})$ equals 1,7 (atomic concentration).

\subsection{Phosphorus(P 2p) and sulfur (S 2p) high-resolution spectra}

In Fig. 5, the deconvolution of $\mathrm{P} 2 \mathrm{p}$ spectra of passive layers formed on 2205 after standard (EP50) and highcurrent density electropolishing (EP1000) is shown. All spectra of the $2 p$ level are composed of the element peaks of the $2 p_{3 / 2}$ and $2 p_{1 / 2}$ level. In case of the P $2 p$ spectra, the difference of the binding energy between $\mathrm{P} 2 \mathrm{p}_{3 / 2}$ and $\mathrm{P}$ $2 \mathrm{p}_{1 / 2}$ equals $0.84 \mathrm{eV}$. The intensity ratio (P $\left.2 \mathrm{p}_{3 / 2}: \mathrm{P} 2 \mathrm{p}_{1 / 2}\right)$ is about $2: 1$. All detected phosphorus spectra showed only one component peak at $\mathrm{BE}\left[\mathrm{P} 2 \mathrm{p}_{3 / 2}\right] \approx 133,5 \mathrm{eV}$, which is a typical value for phosphate ions $\left(\mathrm{PO}_{4}{ }^{3-}\right)$, i.e. iron and/or chromium phosphates, such as $\mathrm{FePO}_{4}, \mathrm{Fe}_{3}\left(\underline{\mathrm{PO}}_{4}\right)_{2}, \mathrm{Cr}_{\underline{P O}}$.
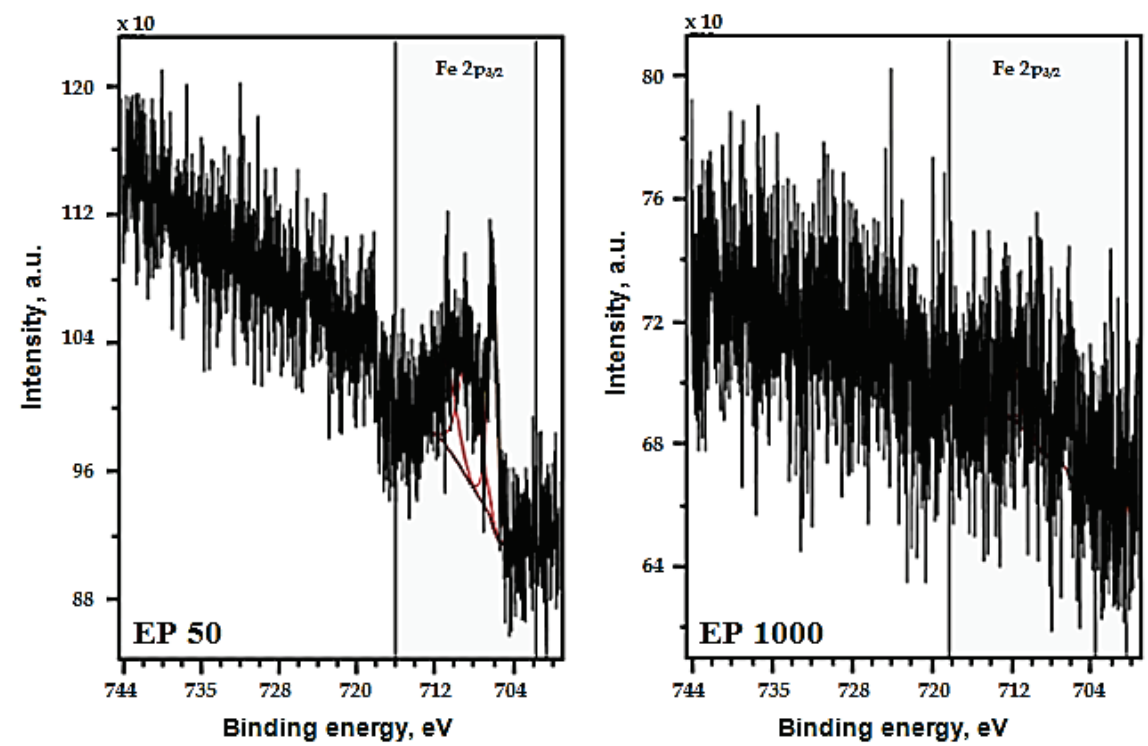

Figure 3 Deconvoluted Fe 2p spectra of passive layers formed on 2205 after standard (EP50) and high-current density electropolishing (EP1000)
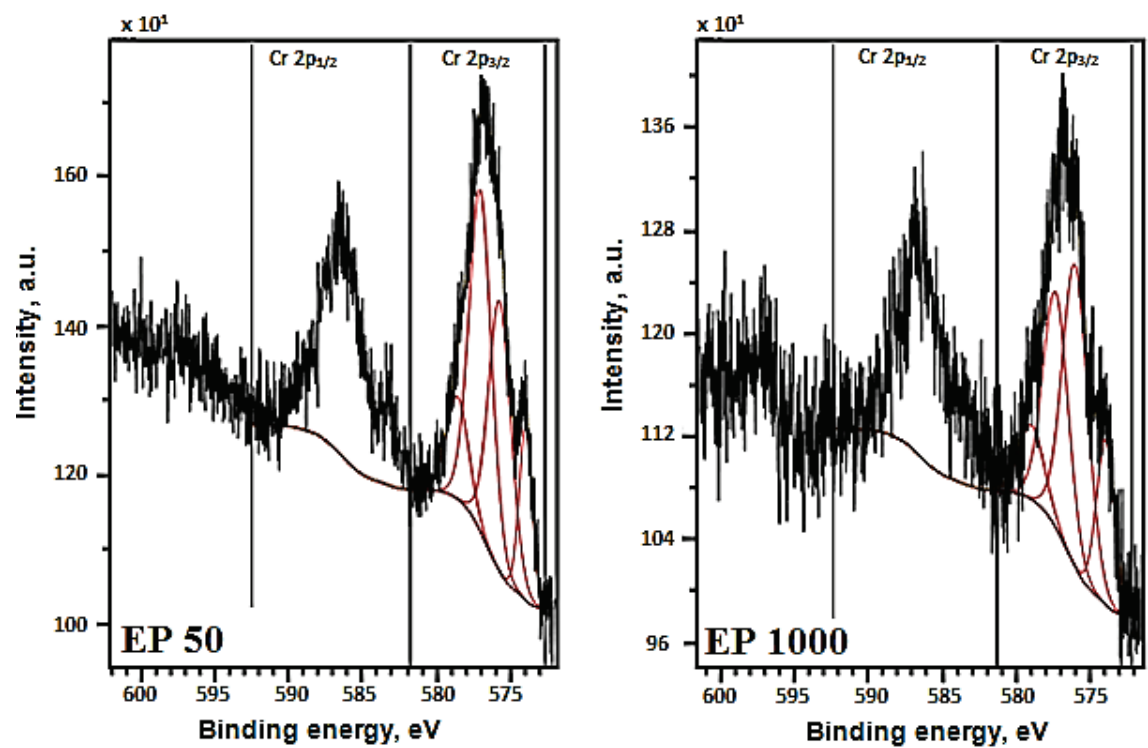

Figure 4 Deconvoluted Cr 2p spectra of passive layers formed on 2205 after standard (EP50) and high-current density electropolishing (EP1000) 
In Fig. 6, the deconvolution of $\mathrm{S} 2 \mathrm{p}$ spectra of passive layers formed on 2205 after standard (EP50) and highcurrent density electropolishing (EP1000) is shown. The difference of the binding energy values between $\mathrm{S} 2 \mathrm{p}_{3 / 2}$ and $\mathrm{S} 2 \mathrm{p}_{1 / 2}$ equals $1,18 \mathrm{eV}$. The intensity ratio of the two peaks $\mathrm{S} 2 \mathrm{p}_{3 / 2}: \mathrm{S} 2 \mathrm{p}_{1 / 2}$ equals $2: 1$. All spectra showed only one component peak at $\mathrm{BE}\left[\mathrm{S} 2 \mathrm{p}_{3 / 2}\right] \approx 168,8 \mathrm{eV}$, which is a typical value for sulfate ions $\left(\mathrm{SO}_{4}{ }^{2-}\right)$, i.e. $\mathrm{FeSO}_{4}$, $\mathrm{Fe}_{3}\left(\mathrm{SO}_{4}\right)_{3}$.

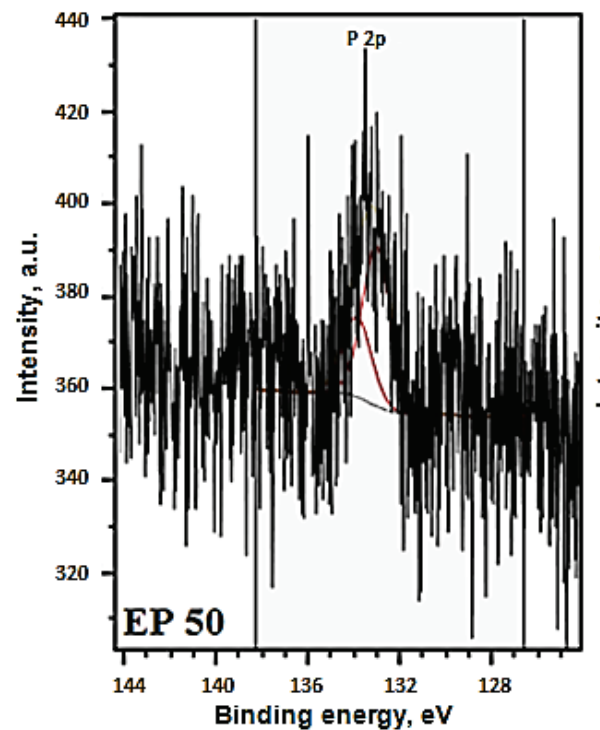

Figure 5 Deconvoluted P 2p spectra of passive layers formed on 2205 after standard (EP50) and high-current density electropolishing (EP1000)

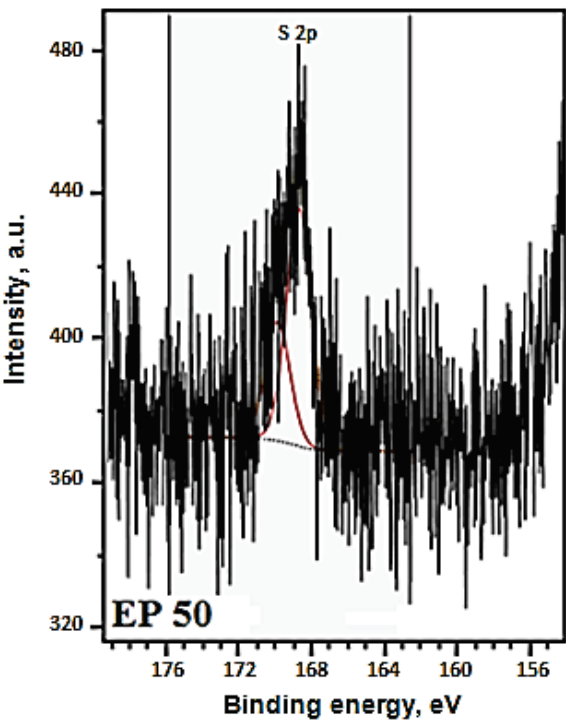

Figure6 Deconvoluted S 2p spectra of passive layers formed on 2205 after standard (EP50) and high-current density electropolishing (EP1000)

\section{Conclusions}

In the paper, the XPS analysis of passive surface layer after new electropolishing method using highcurrent density is presented. In the passive layer there were detected elements, which can be treated as contaminations, such as carbon, nitrogen, sodium, chloride, potassium and partly oxygen as well as components of the passive layer, such as iron, chromium, nickel, molybdenum, manganese, phosphorous, sulfur, silicon and partly oxygen. The iron Fe 2 p signal from the surface after EP1000 is lower than that one after EP50
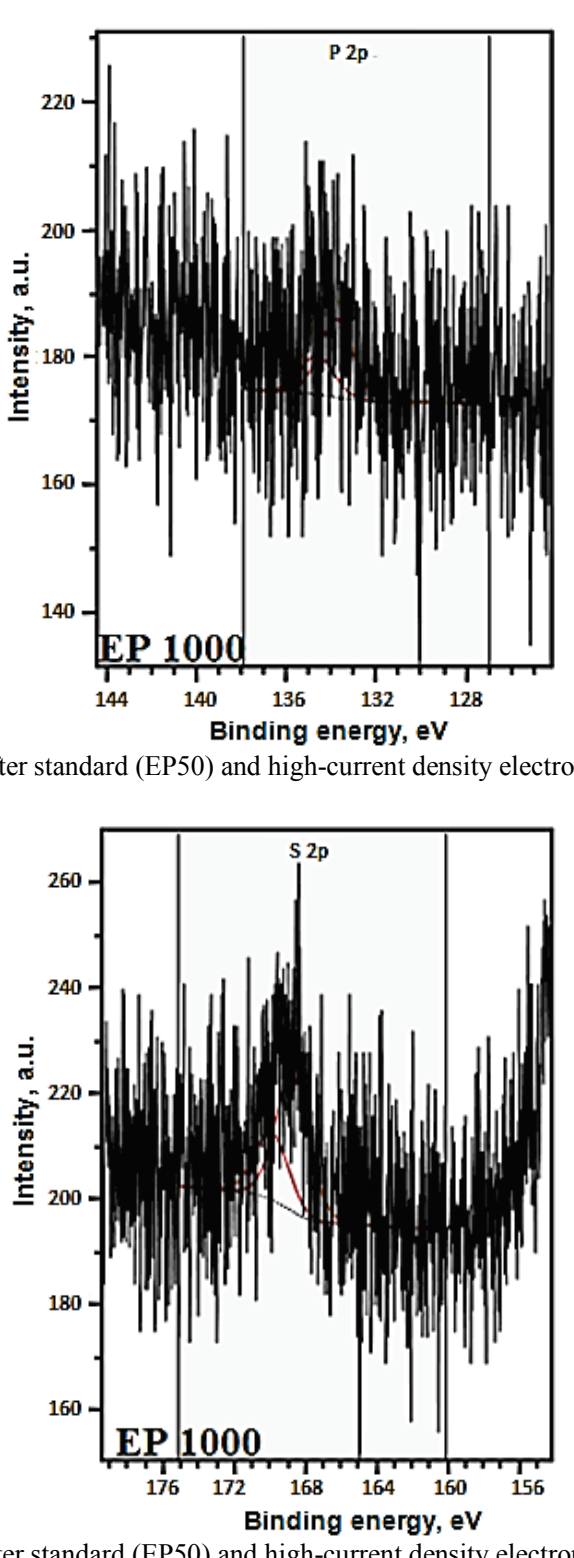

The amount of sulfates in the passive layer after standard electropolishing EP50 was about two times higher than phosphates amount. Phosphorus-to-sulfur coefficient $(\mathrm{P} / \mathrm{S})$ after that electrochemical treatment equals 0,5 (atomic concentration). After high-current electropolishing EP1000, the amount of sulfates in the passive layer was over three times higher than phosphates amount. Phosphorus-to-sulfur coefficient (P/S) after highcurrent electropolishing EP1000 equals 0,3 (atomic concentration)

treatment, what can give a better corrosion resistance for the surface after the new proposed polishing. After both polishing (EP50 and EP1000) the clear chromium $\mathrm{Cr} 2 \mathrm{p}$ signals were recorded, which contain metallic chromium and chromium compounds on the third and sixth stages of oxidation. The sulfur (S 2p) and phosphorus (P 2p) signals indicate that the compounds, which they formed on the surface, are mainly sulfates and phosphates. It should be also noted that chromium-to-iron coefficient $(\mathrm{Cr} / \mathrm{Fe})$ after that electrochemical treatment (EP) equals 1,9 (atomic concentration), while after the high-current electropolishing (EP1000) it equals 1,7 (atomic 
concentration). The second coefficient, i.e. phosphorusto-sulfur (P/S) for EP50 electropolishing equals 0,5 and for EP1000 treatment it is also smaller than for $\mathrm{Cr} / \mathrm{Fe}$ ratio and equals 0,3 . The new method of electropolishing, i.e. High-Current Density Electropolishing is a novel promising way to modify the passive layer formed on duplex steel. The presented results should be treated as the first approach and preliminary study after which also the XPS depth profiles with bigger amount of sweeps will be performed.

\section{References}

[1] Fritz, J. The use of 2205 Duplex Stainless Steel for Pharmaceutical and Biotechnology Applications, International Molybdenum Association, ISBN 978-1907470-25-7, London, 2011, pp. 1-8.

[2] Rokosz, K. Electrochemical Polishing of Steels in a Magnetic Field (Polerowanie elektrochemiczne stali w polu magnetycznym), Monograph No. 219, Copyright by Koszalin University of Technology, Koszalin, 2012 (211 pages).

[3] Hryniewicz, T.; Rokosz, K. Polarization Characteristics of Magnetoelectropolishing Stainless Steels. // Materials Chemistry and Physics. 122, 1(2010), pp. 169-174. DOI: 10.1016/j.matchemphys.2010.02.055

[4] Hryniewicz, T.; Rokicki, R.; Rokosz, K. Corrosion Characteristics of Medical Grade AISI 316L Stainless Steel Surface after Electropolishing in a Magnetic Field. // CORROSION (The Journal of Science and Engineering), Corrosion Science Section. 64, 8(2008), pp. 660-665.

[5] Hryniewicz, T.; Rokosz, K.; Rokicki, R. Electrochemical and XPS studies of AISI 316L stainless steel after electropolishing in a magnetic field. // Corrosion Science. 50, 9(2008), pp. 2676-2681. DOI: 10.1016/j.corsci.2008.06.048

[6] Hryniewicz, T.; Konarski, P.; Rokosz, K.; Rokicki, R. SIMS analysis of hydrogen content in near surface layers of AISI 316L SS after electrolytic polishing under different conditions. // Surface and Coatings Technology. 205, 1718(2011), pp. 4228-4236.

[7] Hryniewicz, T.; Rokosz, K. Analysis of XPS results of AISI 316L SS electropolished and magnetoelectropolished at varying conditions. // Surface and Coatings Technology. 204, 16-17(2010), pp. 2583-2592. DOI: 10.1016/j.surfcoat.2010.02.005

[8] Rokosz, K.; Hryniewicz, T. Pitting corrosion resistance of AISI $316 \mathrm{~L}$ SS in Ringer's solution after magnetoelectrochemical polishing. // CORROSION - The Journal of Science and Engineering. 66, 3(2010), pp. 035004-1...11 (11 pages).

[9] Hryniewicz, T.; Rokosz, K. Biomaterial AISI 316L SS surface film analyses after electropolishing treatments under varied magnetic fields. // World Journal of Engineering. 2011, (Suppl. 1), P439.

[10] Rokosz, K.; Hryniewicz, T.; Raaen, S. Characterization of passive film formed on AISI 316L Stainless Steel after Magnetoelectropolishing in a Broad Range of Polarization Parameters. // Steel Research International. 83, 9(2012), pp. 910-918. DOI: 10.1002/srin.201200046

[11] Rokosz, K.; Hryniewicz, T. XPS measurements of passive film formed on AISI 316L SS after electropolishing in a magnetic field (MEP). // Advances in Materials Science. 12, 4(2013), pp. 13-22. DOI: 10.2478/v10077-012-0012-5

[12] Hryniewicz, T.; Rokosz, K. Corrosion resistance of magnetoelectropolished AISI 316L SS biomaterial. // AntiCorrosion Methods and Materials. 61, 2(2014), pp. 57-64. DOI: 10.1108/ACMM-03-2013-1249
[13] Rokosz, K.; Hryniewicz, T.; Raaen, S.; Valiček, J. SEM/EDX, XPS, Corrosion and Surface Roughness Characterization of AISI 316L SS after Electrochemical Treatment in Concentrated $\mathrm{HNO}_{3}$. // Tehnicki vjesnikTechnical Gazette. 22, 1(2015), pp. 125-131. DOI: 10.17559/TV-20140211130812

[14] Rokosz, K.; Hryniewicz, T.; Rzadkiewicz, S. XPS study of surface layer formed on AISI 316L SS after high-currentdensity electropolishing. // Solid State Phenomena. 227, (2015), pp. 155-158. DOl: 10.4028/www.scientific.net/SSP.227.167

[15] Rokosz, K.; Lahtinen, J.; Hryniewicz, T.; Rzadkiewicz, S. XPS depth profiling analysis of passive surface layers formed on austenitic AISI 304L and AISI 316L SS after High-Current-Density Electropolishing. // Surface and Coatings Technology, 2015, published online at: DOI: 10.1016/j.surfcoat.2015.06.022

[16] Rokosz, K.; Hryniewicz, T. XPS measurements of LDX 2101 duplex steel surface after magnetoelectropolishing. // International Journal of Materials Research. 104, 12(2013), pp. 1223-1232. DOI: 10.3139/146.110984

[17] Rokosz, K.; Simon, F.; Hryniewicz T.; Rzadkiewicz, S. Comparative analysis of passive layers composition on AISI 304L SS after standard and high-current density electropolishing. // Surface and Interface Analysis. 47, (2015), pp. 87-92. (wileyonlinelibrary.com) DOI: $10.1002 /$ sia.5676

[18] Rokosz, K.; Hryniewicz, T. Cr/Fe ratio by XPS spectra of magnetoelectropolished AISI 316L SS using linear, Shirley and Tougaard methods of background subtraction. // Advances in Materials Science. 13, 1(2013), pp. 11-20. DOI: 10.2478/adms-2013-0002

[19] Rokosz, K.; Hryniewicz, T.; Raaen, S. Cr/Fe ratio by XPS spectra of magnetoelectropolished AISI 316L SS fitted by Gaussian-Lorentzian shape lines. // Tehnicki vjesnik/Technical Gazette. 21, 4(2014), pp. 533-538.

[20] Moulder, J. F.; Stickle, W. F.; Sobol, P.; Bomben, K. D.; Chastain, J. Handbook of X-ray Photoelectron Spectroscopy, Perkin-Elmer Corp., Eden Prairie, 1992.

[21] http://srdata.nist.gov

\section{Authors' addresses}

\section{Krzysztof Rokosz}

Tadeusz Hryniewicz, corresponding author Stawomir Rzadkiewicz

Division of Surface Electrochemistry and Engineering, Faculty of Mechanical Engineering, Koszalin University of Technology Racławicka 15-17, PL 75-620 Koszalin, Poland E-mail: rokosz@tu.koszalin.pl

E-mail: tadeusz.hryniewicz@tu.koszalin.pl

\section{Frank Simon}

Department of Polymer Interfaces, Leibnitz Institute of Polymer Research Dresden, Hohe Strasse 6, D-01069 Dresden, Germany E-mail: frsimon@ipfdd.de 